\title{
ESTIMATION OF ENGINE INTAKE AIR MASS FLOW USING A GENERIC SPEED-DENSITY METHOD
}

\section{MICHAL VOJTIIŠEK}

Vehicle Center for Sustainable Mobility, Faculty of Mechanical Engineering, Czech Technical University of Prague, Technická 4, 16607 Prague, Czech Republic, E-mail: michal.vojtisek@fs.cvut.cz

\section{MARTIN KOTEK}

Technical Faculty, Czech University of Life Sciences, Kamýcká 129, 165 21, Prague, Czech Republic

\section{SHRNUTí}

Měření výfukových emisí spalovacích motorů během reálného provozu prenosnými zařizeními umístěnými na palubě vozidla (PEMS) je důležitou součástí hodnocení dopadu nových paliv a technologií na životní prostředí a lidské zdraví. Znalost aktuálního toku výfukových plynů je jedním z nezbytných předpokladů pro takové provozní měření. Jedním z nejjednodušších způsobů je výpočet z toku nasáveného vzduchu, který je vypočten z měřených otáček motoru a tlaku a teploty náplně v sacím potrubí. $\mathrm{V}$ této práci byl obecný algoritmus využívající odhad dopravní účinnosti libovolného běžného čtyřdobého motoru aplikován na tři produkční evropské motory běžně využivané v ČR: těžký a automobilový prèelňovaný vznětový motor, a atmosférický zážehový motor. Vypočtené průtoky nasávaného vzduchu byly porovnány s různými referenčními metodami. Výsledky ukazují, že nejistota stanovení toku nasáveného vzduchu obecným algoritmem je v řádu $10 \%$ pro většinu provozních režimů motoru, kromě př́padů recirkulace velké části výfukových plynů, kdy nejistota vzrůstá na desítky procent. Desetiprocentní nejistota pro motory bez vysoké míry recirkulace výfukových plynů je príijatelná pro mnohá, zvláště průzkumná a orientační, mě̌̌ení emisí za provozu, a může být sní̌ena kalibrací algoritmu pro daný motor.

KLIČOVÁ SLOVA: SPALOVACI MOTOR, TOK NASÁVANÉHO VZDUCHU, DOPRAVNI ÚČINNOST, SOUČINITEL PLNĚNI MOTORU, VÝFUKOVÉ EMISE, MĚřENI EMISI ZA REÁLNÉHO PROVOZU, RDE, PEMS

\section{ABSTRACT}

Measurement of real driving emissions (RDE) from internal combustion engines under real-world operation using portable, onboard monitoring systems (PEMS) is becoming an increasingly important tool aiding the assessment of the effects of new fuels and technologies on environment and human health. The knowledge of exhaust flow is one of the prerequisites for successful RDE measurement with PEMS. One of the simplest approaches for estimating the exhaust flow from virtually any engine is its computation from the intake air flow, which is calculated from measured engine rpm and intake manifold charge pressure and temperature using a generic speed-density algorithm, applicable to most contemporary four-cycle engines. In this work, a generic speed-density algorithm was compared against several reference methods on representative European production engines - a gasoline port-injected automobile engine, two turbocharged diesel automobile engines, and a heavy-duty turbocharged diesel engine. The overall results suggest that the uncertainty of the generic speed-density method is on the order of $10 \%$ throughout most of the engine operating range, but increasing to tens of percent where high-volume exhaust gas recirculation is used. For non-EGR engines, such uncertainty is acceptable for many simpler and screening measurements, and may be, where desired, reduced by engine-specific calibration.

KEYWORDS: INTERNAL COMBUSTION ENGINE, INTAKE AIR FLOW, SPEED-DENSITY, VOLUMETRIC EFFICIENCY, REAL DRIVING EMISSIONS, PORTABLE ON-BOARD EMISSIONS MONITORING SYSTEMS

\section{INTRODUCTION}

The emissions of internal combustion engines, despite major advancements in the engine and exhaust aftertreatment technology, remain to be one of the principal sources of air pollution in most urban areas. Particulate matter in the ambient air is, together with tropospheric ozone, responsible for approximately 430 thousands premature deaths in the European Union (EU) [1], an order of magnitude more than traffic accidents. Particles released by internal combustion engines are considered to constitute a substantial part of this health risk, due to the close proximity of citizens to 
the sources, and due to their small size - typically units to hundreds of nanometers (nm). Most of the particles emitted by internal combustion engines are typically in the size range of tens of nanometers $[2,3]$. Particles of this size readily deposit in human lung alveoli $[4,5]$, have the capacity to penetrate cell membranes and to enter the bloodstream, and are known to cause and/or contribute to a wide variety of health problems [6], including asthma, heart attack or diabetes, and including damage to DNA which may become apparent in subsequent generations. The concentrations of ultrafine particles (units to tens of $\mathrm{nm}$ ) are not uniformly distributed, but are highest along the vehicle travel paths. For this reason, increased risks of asthma, heart attacks and other ailments are often linked to a small distance, usually on the order of one hundred meters, from high traffic intensity roads [7-9]. It has been long known that engine emissions tend to be carefully optimized for the certification test cycle, while being overlooked in other regimes [10-12], such as high rpm, high load, or highly transient operation on one end, and prolonged low-load operation on the other end. As a result, emissions during real-world driving tend to be higher than during certification tests [10-14]. For example, enrichment on gasoline engines during transients and during full load have been known to dramatically increase emissions of hydrocarbons and carbon monoxide (CO) [15] as well as particulate matter (PM) [16-17]. Emissions of polycyclic aromatic hydrocarbons (PAH) were reported to be fifteen times higher during real-world driving than during laboratory tests [18]. $\mathrm{NO}_{\mathrm{x}}$ emissions also tend to be higher during real-world driving or more realistic driving cycles than during the New European Driving Cycle (NEDC) [13-14].

For these reasons, measurement of emissions under real driving conditions, or real-world emissions measurements, are increasingly used to complement traditional chassis or engine dynamometer tests not only for a wide variety of engine and transportation-related research studies, but also as a part of the vehicle/engine type approval process in the EU $[19-20]$ and United States of America (USA) [21-23]. A variety of portable on-board emissions monitoring systems (PEMS) of various degrees of sophistication have been developed to meet these demands [24-34].

PEMS typically monitor the concentrations of the pollutants of interest in the raw exhaust by various analytical means, and multiply these concentrations by the corresponding exhaust flow rate to arrive at instantaneous mass emissions rates. The exhaust flow can be determined by various means [35] involving direct measurement, such as by Pitot tube, or ultrasonic or Vortex flowmeters [15, 26-28], or inference from air-fuel ratio determined from exhaust composition and either measured fuel flow, or measured intake air flow $[15,26,30,36]$. Of these, calculations based on the measured intake air flow are generally the simplest in terms of installation of the instrumentation on the vehicle [35]. On many engines equipped with engine control units (ECU), intake air flow can be read from the ECU via the diagnostic interface. On older engines, or should a stealth installation not visible to the ECU be desired, intake air flow can be measured directly or computed from other measured data. Direct measurement typically involves the installation of a mass air flow meter, generally requiring at least some modification to the engine air intake system [36], and different meters for different size engines. The installation of air or exhaust flow meters is easy in relatively spacious laboratory engine test cells, but difficult on real vehicles. The engines are generally tightly packaged into the vehicle, leaving little space to install bulky sensors, and featuring virtually no straight runs of intake air or exhaust pipe of sufficient length to reach laminar flow. As a result, many on-board systems rely on relatively massive auxiliary equipment, such as a trailer, or at least a contraption across the back of the vehicle housing an exhaust flow sensor $[15,26-28]$.

As an alternative allowing relatively simple fit of a PEMS on the vehicle, computation of the intake air flow using the speeddensity method has been proposed by Vojtisek-Lom and Cobb [35]. The speed-density measurement, commonly used in the $E C U$, relies on the measured engine speed in revolutions per minute (engine rpm), measured temperature and pressure in the intake manifold, engine displacement, air composition, and engine volumetric efficiency [37-40]. Engine volumetric efficiency is defined as the ratio between the air mass flowing into the cylinders from the intake manifold and the air mass theoretically contained in the cylinders at the manifold pressure and temperature [41]. It is dependent on engine type and construction parameters, and for a given engine, varies with engine speed and load [41-45], with the variation with the engine load on a throttled engine being more pronounced than the variation with rpm. Volumetric efficiency under transient conditions has been found to be similar to the corresponding steady-state operation by Smith [46]. In fact, mass air flow (MAF) determined using the speed-density method was found to be more accurate than direct measurement by a mass air flow meter during transients in the work of Stotsky and Kolmanovski [37]. Therefore, it is proposed that the intake air flow is determined from measured engine rpm, measured intake manifold charge pressure and temperature, known engine displacement, and known or estimated engine volumetric efficiency [35]. The engine volumetric efficiency can be determined during chassis dynamometer tests by simultaneous measurement of air and/ or fuel flow by laboratory instruments and calculation of the 
intake air flow from engine rpm and intake manifold pressure measured by on-board sensors. Such data can be, for example, collected during certification laboratory tests for subsequent on-board verification of emissions throughout the life of the engine. However, this is not an established practice, and volumetric efficiency data is not always available. A generic algorithm for estimation of mass air flow based on volumetric efficiency dependency on throttling, universal for all engine types, has been proposed by Vojtisek-Lom.and Cobb [30]:

$\operatorname{MAF}[\mathrm{g} / \mathrm{s}]=\mathrm{M}_{\text {air }} \cdot \mathrm{V}_{\mathrm{d}} \cdot \mathrm{n}_{\mathrm{vol}} \cdot\left(\mathrm{MAP}-\left(\mathrm{p}_{\mathrm{atm}} / \mathrm{CR}\right)\right) /(\mathrm{R} \cdot \mathrm{IAT})$

where:

$\mathrm{M}_{\text {air }} \quad$ is molecular weight of air of $28.9 \mathrm{~g} \mathrm{~mol}^{-1}$

$\mathrm{V}_{\mathrm{d}} \quad$ is engine displacement volume in $\mathrm{dm}^{3}$

$\mathrm{n}_{\mathrm{vol}} \quad$ is dimensionless engine volumetric efficiency multiplier

MAP is intake manifold absolute pressure in $\mathrm{kPa}$

$\mathrm{p}_{\mathrm{atm}} \quad$ is barometric pressure in $\mathrm{kPa}$

$\mathrm{CR}$ is dimensionless engine compression ratio

$\mathrm{R} \quad$ is universal gas constant of $8.314 \mathrm{~J}_{\mathrm{mol}} \mathrm{m}^{-1} \cdot \mathrm{K}^{-1}$

IAT is intake manifold charge temperature in $\mathrm{K}$

Such calculation was aimed as a general approximation of the mass air flow on "ordinary" engines not using at the time advanced features such as high EGR rates, high expansion ratio, or valve deactivation. Most utilizations of the monitoring system have used $n_{\text {vol }}=0.95$, which is equivalent, at 9.5:1 compression ratio, to a volumetric efficiency of 0.85 at full load for all engine rpm. This value has been used in multiple sets of laboratory comparison tests in the U.S., yielding, after combination with measured exhaust gas composition, $\mathrm{CO}_{2}$ mass emissions rates which were generally comparable to the laboratory measurements [47]. All comparison measurements data available have been performed about a decade ago on engines on U.S. market, which, in general, have much higher displacement, higher power, and lower real-world emissions than their European counterparts. Also, with engine parameters markedly improving over the time, improvements are also expected in the engine volumetric efficiency. With the increased interest in PEMS measurements in Europe, and given the advantages of the speed-density flow calculation in terms of simplicity of installation, a question arises as to whether the same or similar algorithm can be used on in-use engines in the EU.

The purpose of this work is to assess the applicability of the generic speed-density equation (1) to production engines in Europe. A gasoline port fuel-injected (PFI) automobile engine, a two turbocharged diesel automobile engines, and a heavy-duty diesel engine were selected as representative engines. The work was motivated by continued present and anticipated future use of this method for measurement of real driving emissions, and in addition, by anticipated use of the air flow signal to drive an on-board proportional particle sampling system.

\section{EXPERIMENTAL}

Four production engines were used under the following test conditions:

a) An Iveco Tector 6-liter, inline six-cylinder, $180 \mathrm{~kW}$ turbodiesel engine with Common Rail injectors, operated on a transient engine dynamometer on diesel fuel according to Engine Transient Cycle (ETC) and World Harmonized Transient Engine Cycle (WHTC); a laboratorygrade mass air flow meter (Sensyflow, ABB) was used as a reference mass air flow measurement, with an estimated uncertainty of less than $1 \%$ under steady-state conditions.

b) A model year 2007 Renault Traffic with a 2-liter, fourcylinder, $66 \mathrm{~kW}$ turbodiesel engine, operated on diesel fuel in and around Liberec, Czech Republic and Zvolen, Slovakia; the on-board mass air flow sensor was used as a reference mass air flow measurement, with uncertainty believed to be within $10 \%$ at steady-state conditions

c) A model year 2008 Škoda Octavia car with a 2-liter, fourcylinder, 103 kW turbodiesel engine, operated on diesel fuel on the road around the city of Prague; the enginereported mass air flow value was used as a reference. The uncertainty of the reported air flow sensor was estimated, by pooling knowledge from multiple sources, to be around $5 \%$ during steady-state conditions.

d) A Škoda Fabia 1.2 HTP, 1.2-liter, three-cylinder, naturally aspirated, port fuel injected engine (manufacturer code AWY) operated on an eddy-current engine dynamometer on gasoline at steady-state conditions covering the entire engine operating map; a non-critical orifice coupled with a U-manometer using water as a working fluid was, together with barometric pressure and ambient temperature measurements, used as a reference mass air flow measurement, and a fuel consumption derived from online reading of the mass of the fuel tank placed on an industrial scale (Soehnle, $30 \mathrm{~kg}$ range, $2 \mathrm{~g}$ repeatability) was used as a reference fuel flow measurement.

All engines were operated on "street fuels", unleaded gasoline with octane rating (mean of motor and research octane numbers) of 95, and European (EN 590) diesel fuel with a cetane number of approximately 55 . As the fuel and lubricating oil quality and composition does not have a profound effect on engine volumetric efficiency, fuels and oils were not examined in detail. 


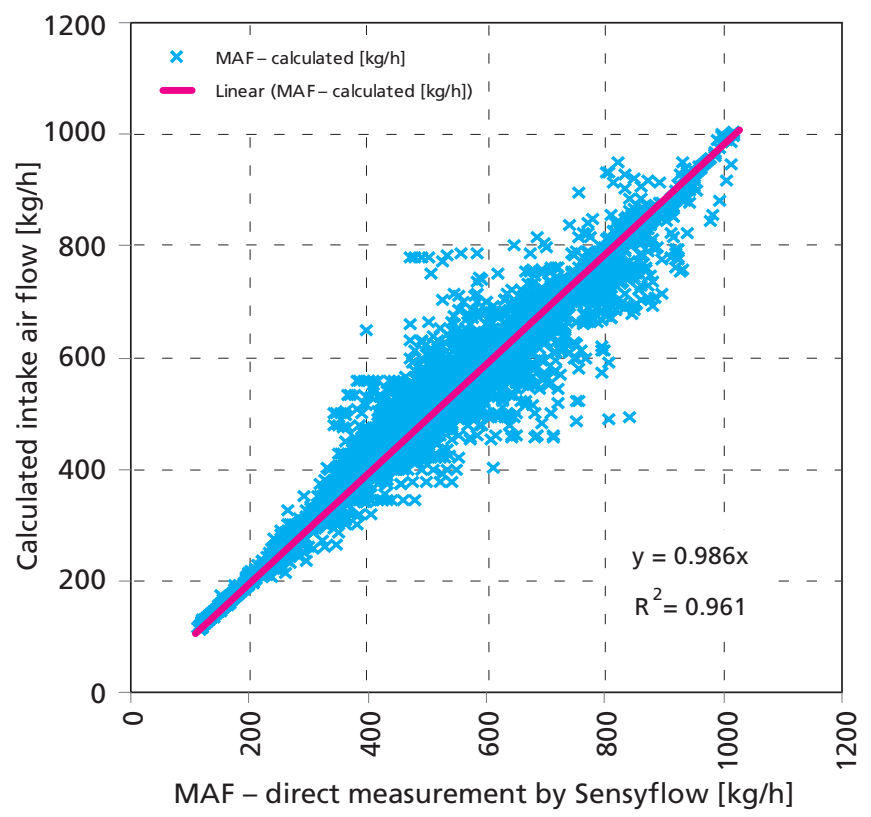

FIGURE 1: Comparison of calculated mass air flow with mass air flow derived from a laboratory-grade mass air flow meter on Iveco Tector heavy-duty on-road diesel engine.

OBRÁZEK 1: Porovnání vypočteného toku nasávaného vzduchu s tokem změřeným referenčním laboratorním průtokomětem na těžkém vznětovém motoru Iveco Tector.

The Iveco engine was fitted with an intake manifold pressure sensor (0-400 $\mathrm{kPa}, 0.25 \%$ accuracy, JSP), and the engine dynamometer was used as the source of engine rpm and intake air temperature data, with declared accuracy of $1 \mathrm{rpm}$ and $1 \mathrm{C}$ at steady-state conditions. On the other two engines, engine rpm and intake air flow temperature and pressure data were extracted from the ECU using the European On-Board Diagnostics (EOBD) interface. The EOBD data uncertainty was estimated to be $1-10 \mathrm{rpm}, 1-2 \mathrm{kPa}$ and $1-2 \mathrm{C}$, yielding approximately $2 \%(1-3 \%$ range depending on operating conditions) uncertainty on diesel and approximately $3 \%$ $(1-4 \%)$ uncertainty on gasoline engine. For all engines, the mass air flow data was calculated on the second-by-second basis using formula (1) using $n_{\text {vol }}=0.95$, a value suggested by Vojtisek-Lom based on experimental fit of data from multiple engines [30]. On the gasoline engine, additional reference mass air flow reading was obtained from the measured fuel mass rates and from the air-fuel ratio computed from measured exhaust gas composition using the original Brettschneider formula [48].

\section{RESULTS AND DISCUSSION}

Comparison of the calculated (using speed-density method) and measured mass air flows is plotted in Figure 1 for the Iveco Tector heavy-duty diesel engine, in Figure 2 for the Škoda

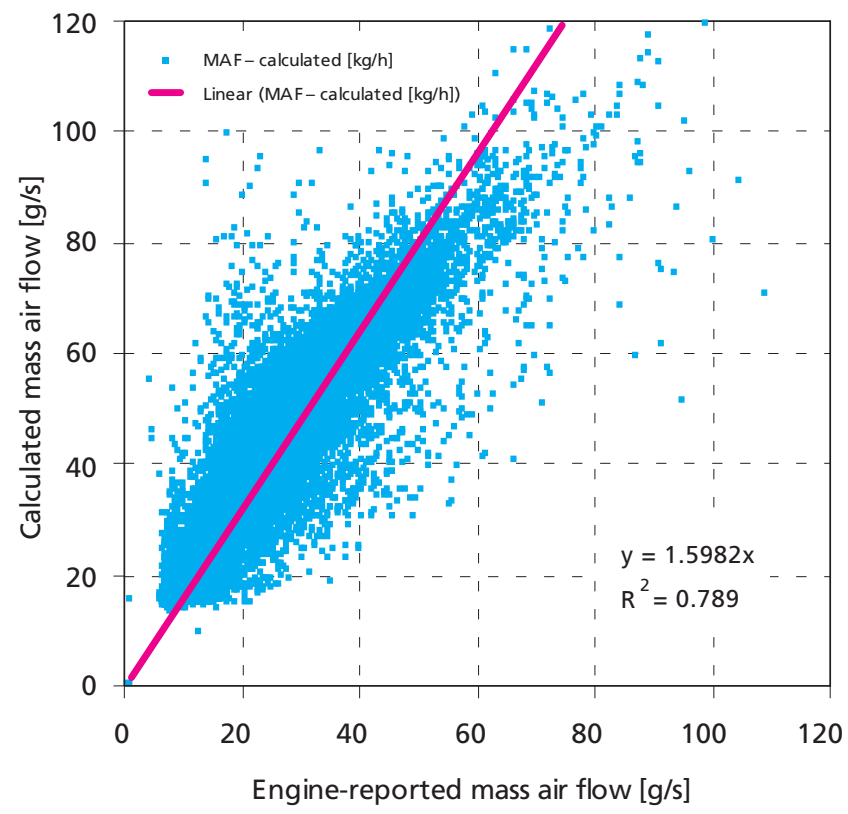

FIGURE 2: Comparison of calculated mass air flow with mass air flow reported by the ECU on a Škoda Octavia 2.0 TDI diesel engine. OBRÁZEK 2: Porovnání vypočteného toku nasávaného vzduchu s tokem udávaným rrídící jednotkou motoru na vznětovém motoru Škoda Octavia 2.0 TDI.

Octavia automobile turbodiesel engine, in Figures 3 and 4 for the Renault Traffic automobile turbodiesel engine during mostly freeway and city/highway operation, respectively, and in Figures 5 and 6 for the automotive spark ignition engine. For the spark ignition engine, comparison of the calculated mass air flow with mass air derived from mass air flow measured with the orifice is plotted in Figure 5. Comparison of calculated mass air flow with mass air flow derived from fuel consumption and exhaust measurement is given in Figure 6 .

The overall comparison was reasonably good for the heavy-duty diesel and automobile gasoline engines, and worse for the two automobile turbodiesel engines with high EGR rates.

For the Iveco Tector engine, the primary source of difference was the inability to match the two sets of data in time, due to the highly transient nature of the test cycle and variable time lag between the measurements given, among others, the volume of air between the mass air flow sensor and the intake manifold.

For the Škoda Octavia engine, the calculated mass air flow was majorly overestimated throughout the engine operating range. The overestimation was highest, up to a factor of about two, when EGR was used, which was primarily during the operation at low to moderate engine loads. 


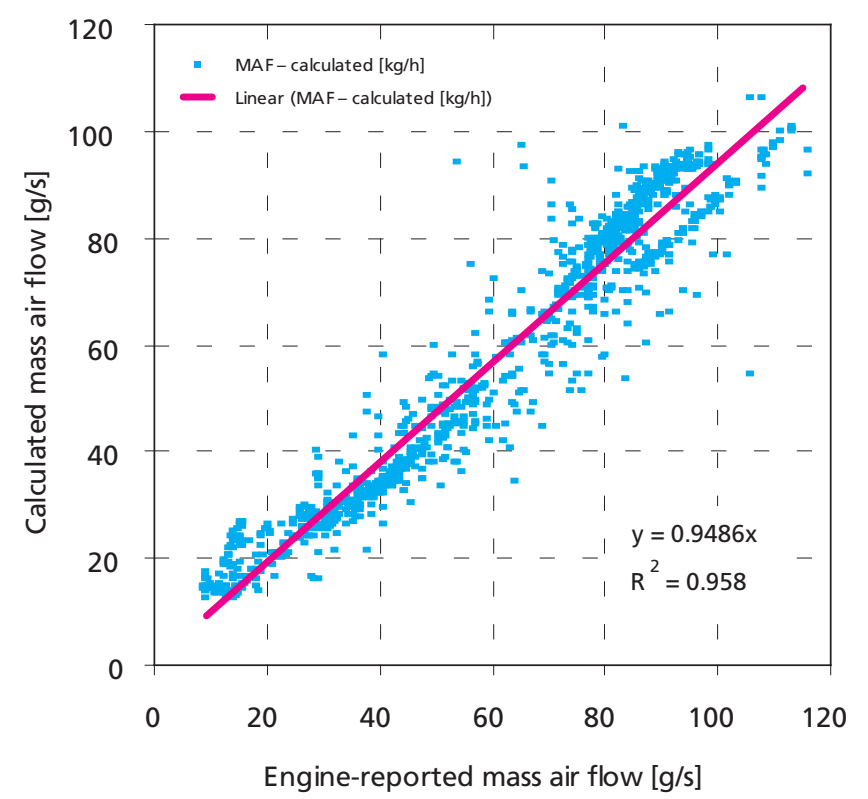

FIGURE 3: Comparison of calculated mass air flow with mass air flow derived from an on-board mass air flow sensor on a Renault Traffic turbodiesel engine during freeway operation.

OBRÁZEK 3: Porovnání vypočteného toku nasávaného vzduchu s tokem změřeným palubním snímačem váhy vzduchu na vznětovém motoru Renault Traffic při jízdě po dálnici.

For the Renault Traffic engine, a difference between freeway and city/highway operation was observed. When the EGR was not used due to low engine temperature or higher speed, the calculated mass air flow was underestimated by around $10 \%$ during lower and medium loads at moderate rpm and generally in line with the measurement during higher loads and higher rpm. During city and highway operation, the calculated flow was overestimated due to the large portion of the flow through the engine being recirculated back into the intake, and therefore being accounted for twice. Large differences are limited to small number of points, are not systematic, and are attributed primarily to different dynamic responses of sensors and time alignment issues.

For the Škoda Fabia spark ignition engine, the ratio between the calculated mass air flow and the reference mass air flow is plotted in Figure 7 using the measured air flow and in Figure 8 using the air flow derived from the fuel consumption and emissions data. The calculated mass air flow is: a) underestimated by up to around $10 \%$ for $3000-4000 \mathrm{rpm}$ at moderate and higher loads, where the engine volumetric efficiency appears to be the highest by the choice of the engine designers; b) overestimated at $5000 \mathrm{rpm}$ where the engine volumetric efficiency is lower due to higher rpm; c) not statistically significantly different from reference

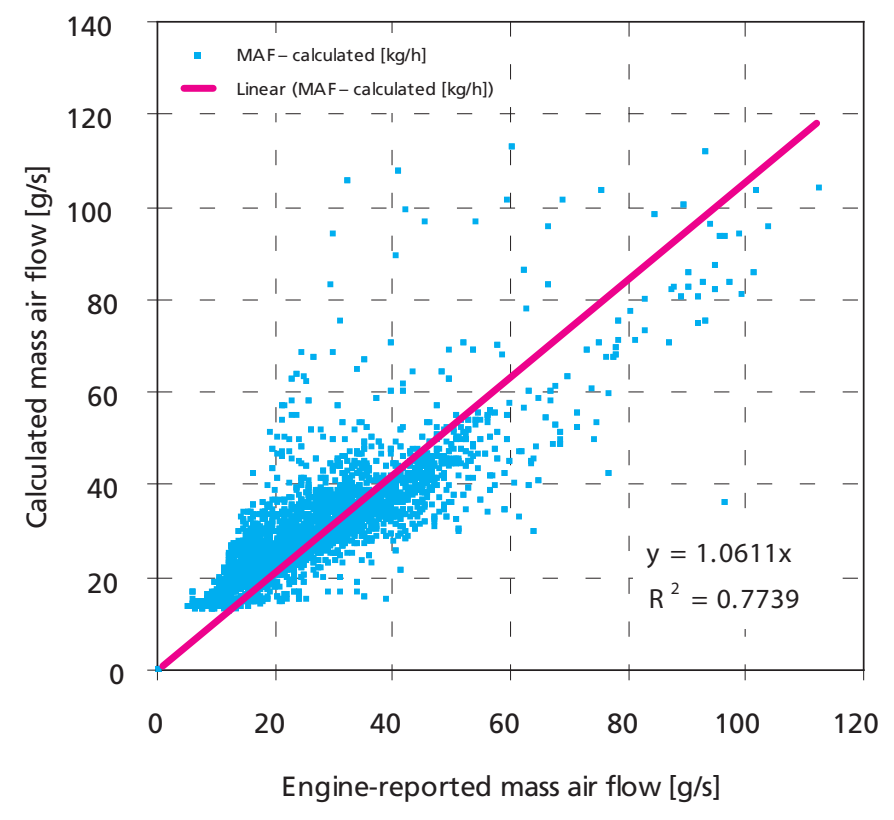

FIGURE 4: Comparison of calculated mass air flow with mass air flow derived from an on-board mass air flow sensor on a Renault Traffic turbodiesel engine during city and highway driving.

OBRÁZEK 4: Porovnání vypočteného toku nasávaného vzduchu s tokem změřeným palubním snímačem váhy vzduchu na vznětovém motoru Renault Traffic při jízdě v městském a mimoměstském provozu.

measurements at moderate speeds and loads. At idle, the difference is believed to be due primarily to the uncertainty in reference measurement: At lower air flows and lower fuel consumption rates the relative uncertainties of both air flow measurement by an orifice and fuel flow measurements by continuous weighing of the fuel tank are higher, and the two reference measurements are not in agreement.

Overall, for engines not featuring high EGR rates, the differences between the intake air flow inferred from the generic speed-density calculation and reference measurements were up to around $10 \%$ for most engine operating points. It can be argued that for simple measurements, such as during screening for excess emissions on the order of hundreds of percent, such uncertainty is acceptable. With the nature of the uncertainty being that of a systematic bias, the measurement repeatability can be little affected for some types of comparative measurements along a given route, where engine operating conditions and thus biases in volumetric efficiency are comparable. This can be the case, for example, with the investigation of the effects of new fuels or retrofit devices. For precision measurements, such as certification process, the volumetric efficiency map can be inferred by running comparative measurements in a laboratory, or with a fitted reference mass air flow sensor. 


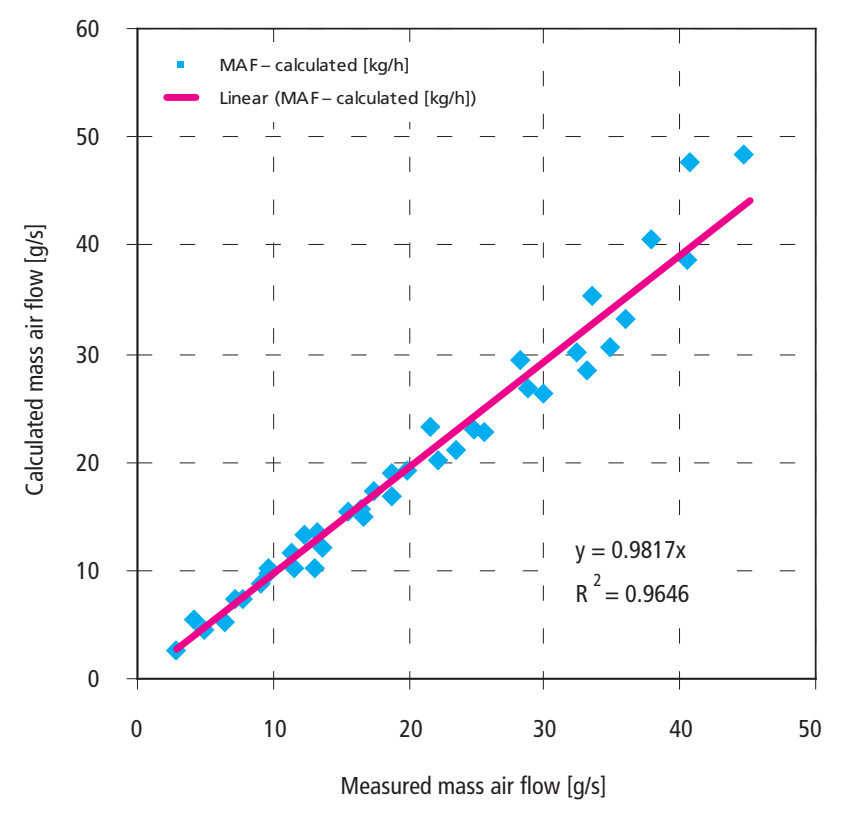

FIGURE 5: Comparison of calculated mass air flow with mass air flow computed from orifice measurement on a Škoda Fabia 1.2 HTP gasoline engine.

OBRÁZEK 5: Porovnání vypočteného toku nasávaného vzduchu s tokem změřeným tlakovým spádem na clonce na zážehovém motoru Škoda Fabia 1.2 HTP.

For engines with high EGR rates, the speed-density calculation is not useful without accounting for the recirculated volume, which would require, for example, measurement of $\mathrm{CO}_{2}$ concentrations in the intake manifold, which can be readily done with a miniature NDIR analyzer, sampling from the same access point used for intake manifold pressure measurement. Most such engines are computer-controlled, and a more simple method could be the extraction of the mass air flow data through the engine diagnostic interface.

The generic speed-density calculation algorithm shown here is applicable to ordinary contemporary four-cycle engines with no or low EGR rates. The uncertainty is expected to be higher for engines with high EGR rates, high expansion ratio engines where effective compression ratio given by valve timing is substantially smaller than the compression ratio given by engine geometry, engines with tuned intake manifolds, engines with valve deactuation, and, on the other end of the scale, older engines with less optimized air flow system. On such engines, and where measurement uncertainty needs to be reduced, calibration of the method in a laboratory against a reference air flow measurements is recommended. On the other hand, on many such modern engines, air flow rates can be often extracted from the ECU.

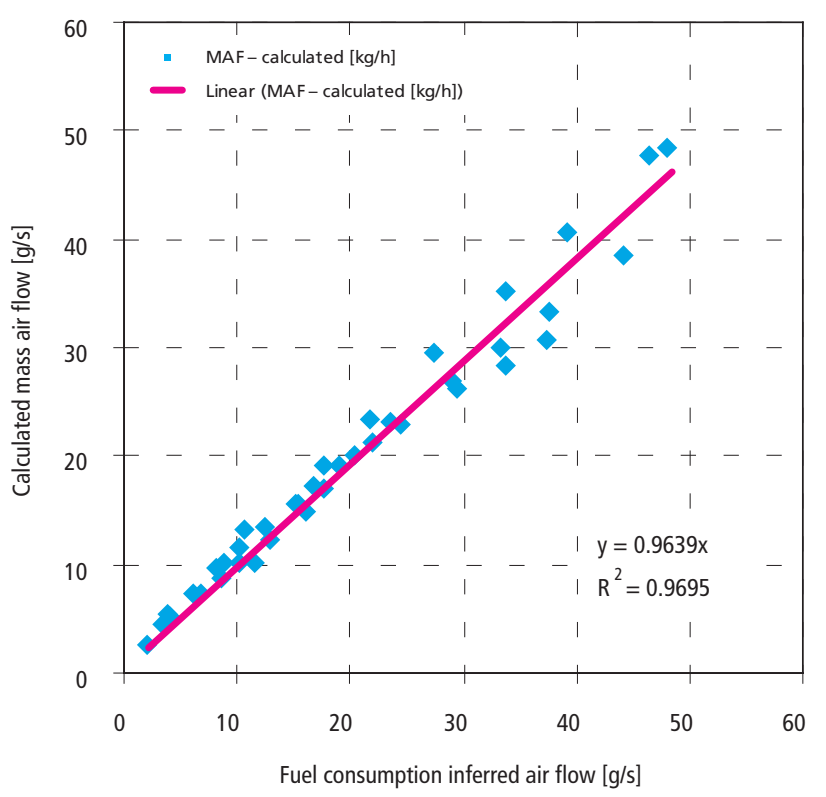

FIGURE 6: Comparison of calculated mass air flow with mass air flow computed from measured fuel consumption and air-fuel ratio computed from exhaust composition on a Škoda Fabia 1.2 HTP gasoline engine. OBRÁZEK 6: Porovnání vypočteného toku nasávaného vzduchu s tokem vypočteným ze změřeného průtoku paliva a směšovacího poměru vypočteného ze změřeného toku výfukových plynů na zážehovém motoru Škoda Fabia 1.2 HTP.

\section{CONCLUSIONS}

The generic speed-density calculation of an internal combustion engine intake air flow has been assessed in this work. The knowledge of intake air flow and its simple measurement are important for measurement of real-driving emissions using onboard monitoring systems.

The speed-density calculation based on measured engine rpm and intake air pressure and temperature and a universal generic volumetric efficiency coefficient was compared to different types of reference measurements: a laboratory mass flow meter on a heavy-duty diesel engine, a hot-wire anemometer on an automobile turbocharged diesel engine, and orifice and mass fuel flow measurement on an automobile spark ignition engine. The overall results suggest that unless high rates of EGR are used, the uncertainty of the generic speed-density method is on the order of $10 \%$ throughout most of the engine operating range. Such uncertainty is acceptable for many types of on-board measurements and can be further improved, where necessary, by using individual volumetric efficiency maps applicable to the given engine. For engines with high EGR rates, knowledge of EGR rate is needed. 


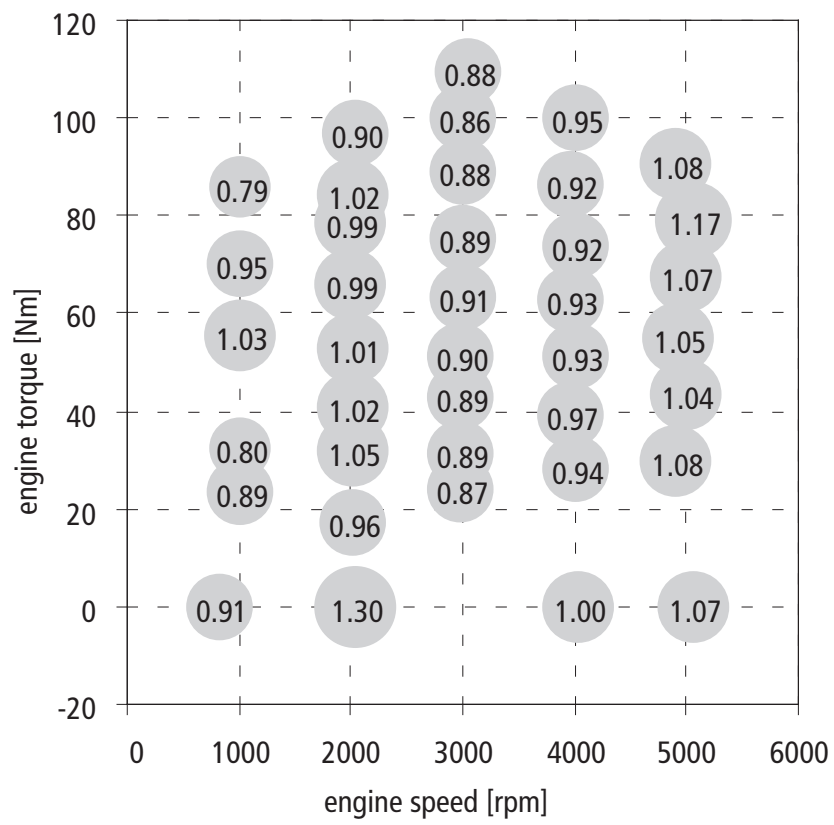

FIGURE 7: Ratio of calculated to measured mass air flow at different engine speed and loads on a Škoda Fabia 1.2 HTP gasoline engine. OBRÁZEK 7: Poměr mezi vypočteným a změěeným tokem nasáveného vzduchu pro různé kombinace otáček a zatížení zážehového motoru Škoda Fabia 1.2 HTP.

\section{ACKNOWLEDGEMENTS}

This work has been realized with the contribution from the following sources: The Ministry of Education, Youth and Sports program NPU I (LO), project \# L01311 "Development of Vehicle Centre of Sustainable Mobility"; European Social Fund project "Support of inter-sectoral mobility and quality enhancement of research teams at Czech Technical University in Prague", CZ.1.07/2.3.00/30.0034; EU LIFE program, project LIFE10 ENV/CZ/651 MEDETOX; Czech Grant Foundation project 13-01438S BIOTOX - "Mechanisms of toxicity of biofuel particulate emissions"; and Czech University of Life Sciences in Prague Internal Grant Agency, project 2014:31150/1312/3116 "Evaluation of the environmental benefits of bioethanol blending into motor fuels".

\section{REFERENCES}

[1] Air Quality in Europe 2013. European Environment Agency. EEA Report 9/2013, ISSN 1725-9177, online at http://www. eea.europa.eu/publications/air-quality-in-europe-2013

[2] Kittelson D. B., Watts W. F., Johnson J. P. (2006). On-road and Laboratory Evaluation of Combustion Aerosols Part 1: Summary of Diesel Engine Results. In: Journal of Aerosol Science, 37, 2006, pp. 913-930.

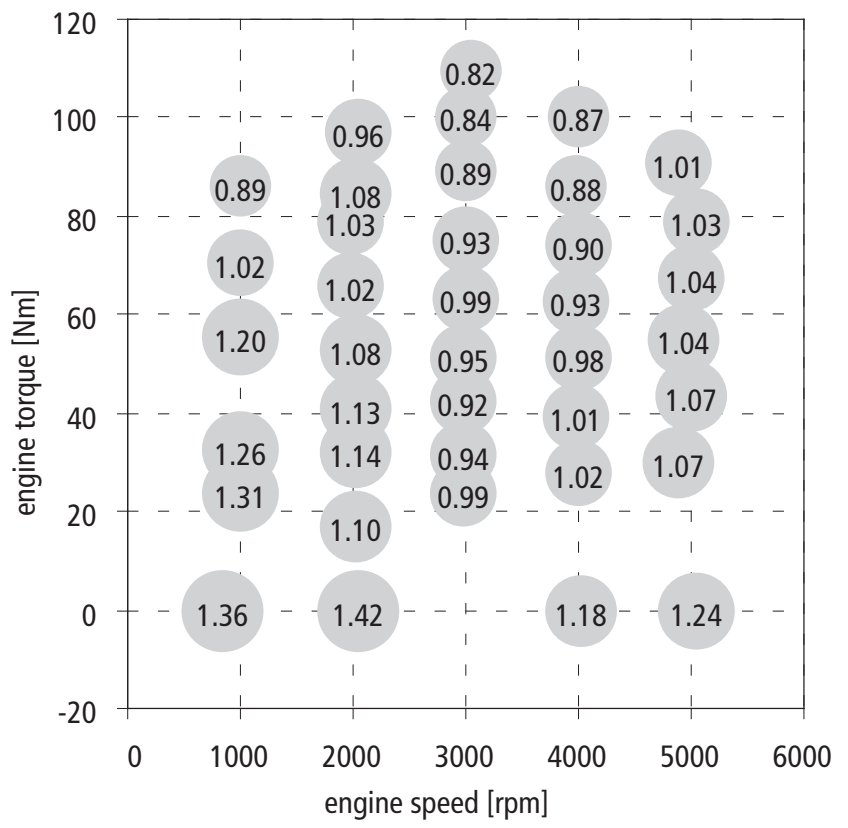

FIGURE 8: Ratio of calculated to fuel-consumption-derived mass air flow at different engine speed and loads on a Škoda Fabia 1.2 HTP gasoline engine.

OBRÁzEK 8: Poměr mezi vypočteným tokem nasáveného vzduchu a tokem nasávaného vzduchu vypočteným z měřené spotřeby paliva pro různé kombinace otáček a zatižení zážehového motoru Škoda Fabia 1.2 HTP.

[3] Kittelson D. B., Watts W. F., Johnson J. P., Schauer J., and Lawson D. R. (2006). On-road and Laboratory Evaluation of Combustion Aerosols Part 2: Summary of Spark Ignition Engine Results. In: Journal of Aerosol Science, 37, 2006, pp. $931-949$.

[4] Gehr P., Blank, F., Rothen-Rutishauser B. (2006). Fate of inhaled particles after interaction with the lung surface. In: Paediatric Respiratory Reviews, Vol. 7, Suppl. 1, 2006, pp. S73-S75.

[5] Gerde P., Muggenburg B.A., Lundborg M., Dahl A.R. (2001). The rapid alveolar absorption of diesel soot-adsorbed benzo(a)pyrene: bioavailability, metabolism and dosimetry of an inhaled particle-borne carcinogen. In: Carcinogenesis 22, pp. $741-749$.

[6] Künzli N. R., Kaiser R., Medina S., Studnicka M., Chanel O., Filliger P., Herry M., Horak F., Puybonnieux-Texier V., Quénel P., Schneider J., Seethaler R., Vergnaud J.-C., Sommer H. (2000). Public-health impact of outdoor and traffic-related air pollution: a European assessment, In: The Lancet 356, pp. 895-901.

[7] Balmes J.R., Earnest G., Katz P.P., Yelin E.H., Eisner M.D., Chem H., Trupin L., Lurmann F., Blanc P.D. (2009). Exposure to traffic: Lung function and health status in adults with 
asthma. In: Journal of Allergy and Clinical Immunology 123/3, pp. 626-631.

[8] Lewtas J. (2007). Air pollution combustion emissions: Characterization of causative agents and mechanisms associated with cancer, reproductive, and cardiovascular effects. In: Mutation Research 636, pp. 95-133.

[9] McEntee J.C., Ogneva-Himmelberger Y. (2008). Diesel particulate matter, lung cancer, and asthma incidences along major traffic corridors in MA, USA: A GIS analysis. In: Health \& Place 14, pp. 817-828.

[10] Vojtišek M., Fenkl M., Dufek M., Mareš J. (2009). Off-cycle, real-world emissions of modern light-duty diesel vehicles. SAE Technical Paper 2009-24-0148. Society of Automotive Engineers, Warrensdale, PA, USA, 2009, ISSN 0148-7191.

[11] Weiss M., Bonnel P., Hummel R., Provenza A., Manfredi U. (2011). On-Road Emissions of Light-Duty Vehicles in Europe. In: Environmenal Science and Technology, 45, 19, 2011, pp. 8575-8581, doi: 10.1021/es2008424.

[12] Weiss M., Bonnel P., Kuehlwein J., et al. (2012). Will Euro 6 reduce the $\mathrm{NO}_{x}$ emissions of new diesel cars? - Insights from on-road tests with Portable Emissions Measurement Systems (PEMS). In: Atmospheric Environment, 62, 2012, pp. 657-665. doi: 10.1016/j.atmosenv.2012.08.056.

[13] Favre C., Bosteels D., May J. (2013). Exhaust Emissions from European Market-Available Passenger Cars Evaluated on Various Drive Cycles. SAE Technical Paper 2013-24-0154.

[14] Lee T., et al. (2013). Variability in operation-based $\mathrm{NO}_{\mathrm{x}}$ emission factors with different test routes, and its effects on the real-driving emissions of light diesel vehicles. In: Science of The Total Environment, 2013/461, pp. 377-385.

[15] Kelly N.A., Groblicki P.J. (1993). Real-world emissions from a modern production vehicle driven in Los Angeles. In: Journal of the Air \& Waste Management Association, 43, 1993, pp. 1351-1357.

[16] Kayes D., Hochgreb S., Maricq M., Podsiadlik D. et al. (2000). Particulate Matter Emission During Start-up and Transient Operation of a Spark-Ignition Engine (2): Effect of Speed, Load, and Real-World Driving Cycles. SAE Technical Paper 2000-01-1083, 2000, doi: 10.4271/2000-01-1083.

[17] Kittelson D.B. (1998). Engines and Nanoparticles. A review. In: Journal of Aerosol Science, 29, pp. 575-588.

[18] Kristensson A., et al. (2004). Real-world traffic emission factors of gases and particles measured in a road tunnel in Stockholm, Sweden. In: Atmospheric Environment, 38, 2004, pp. 657-673.

[19] Vlachos T., Bonnel P., Perujo A., Weiss M. et al. (2014). In-Use Emissions Testing with Portable Emissions Measurement Systems (PEMS) in the Current and Future European Vehicle Emissions Legislation: Overview,
Underlying Principles and Expected Benefits," In: SAE Int. J. Commer. Veh. 7(1), pp. 199-215, 2014, doi: 10.4271/201401-1549.

[20] Institute for Energy and Transport, European Commission: Real-world emissions and activity monitoring of engines and vehicles in support to the European Emissions control legislation. Online at http://iet.jrc.ec.europa.eu/pems/ portable-emissions-measurement-systems-pems

[21] Feist M., Sharp C., and Spears M. (2009). Determination of PEMS Measurement Allowances for Gaseous Emissions Regulated Under the Heavy-Duty Diesel Engine In-Use Testing Program: Part 1 - Project Overview and PEMS Evaluation Procedures. SAE Technical Paper 2009-01-0940, 2009, doi: 10.4271/2009-01-0940.

[22] Sharp C., Feist M., Laroo C., and Spears M. (2009). Determination of PEMS Measurement Allowances for Gaseous Emissions Regulated Under the Heavy-Duty Diesel Engine In-Use Testing Program Part 3 - Results and Validation. SAE Technical Paper 2009-01-0938, 2009, doi: 10.4271/2009-01-0938.

[23] United States Code of Federal Register, 40 CFR Part 1065, Subpart J - Field Testing and Portable Emission Measurement Systems. Online at http://www.law.cornell. edu/cfr/text/40/part-1065/subpart-J

[24] Lenaers G. (1996). On-board real life emission measurements on a 3-way catalyst gasoline car in motorway-, rural- and city traffic and two Euro-1 diesel city buses. In: Science of the Total Environment 189/190, 1996, pp. 139-147.

[25] Lenaers G., Pelkmans L. and Debal P. (2003). The Realisation of an On-board Emission Measuring System Serving as a R\&D Tool for Ultra Low Emitting Vehicles. In: Int. J. Veh. Design, Vol.31, No. 3, pp. 253-268.

[26] Dearth M.A., et al. (2005). SemtechD: The Chassis Roll Evaluation of a Commercial Portable Emission Measurement System (PEMS). SAE Technical Paper 2005-01-0673, Society of Automotive Engineers, Warrensdale, PA, USA, 2005.

[27] Breton Leo (2000). Real-time on-road vehicle exhaust gas modular flowmeter and emissions reporting system. United States patent no. 6148656, 2000.

[28] Nakamura H., Kihara N., Adachi M., Ishida K. (2002). Development of a Wet-Based Ndir and Its Application to On-Board Emission Measurement System. SAE Technical Paper 2002-01-0612. Society of Automotive Engineers, Warrensdale, PA, USA, 2002.

[29] Nakamura H., Akard M., Porter S., Kihara N. et al. (2007). Performance Test Results of a New On Board Emission Measurement System Conformed with CFR Part 1065. SAE Technical Paper 2007-01-1326, 2007, doi: 10.4271/2007-01-1326. 
[30] Vojtíšek-Lom M., Cobb J.T. (1998). On-road light-duty vehicle emission measurements using a novel inexpensive on-board portable system. Proceedings of the $8^{\text {th }}$ CRC On-road vehicle emissions workshop, San Diego, California, USA, 1998.

[31] Vojtíšek-Lom M., Allsop J.E. (2001). Development Of HeavyDuty Diesel Portable, On-Board Mass Exhaust Emissions Monitoring System With NOx, CO2 And Qualitative PM Capabilities. SAE Technical Paper Series, 2001-01-3641. Society of Automotive Engineers, Warrensdale, PA, USA, 2001.

[32] Vojtí̌̌ek-Lom M., Wilson P.J., Julian M. (2004). Enhanced real-time, real-world vehicle emissions measurement using an on-board FTIR analyzer. 14 ${ }^{\text {th }}$ CRC On-road Vehicle Emissions workshop, San Diego, California, USA, 2004.

[33] Daham B., et al. (2005). Application of a Portable FTIR for Measuring On-Road Emissions. SAE Technical Paper 200501-0676. Society of Automotive Engineers, Warrensdale, PA, USA, 2005.

[34] Collins J., et al. (2007). Measurements of in-use emissions from modern vehicles using an on-board measurement system. In: Environmental Science \& Technology, 41, 2007, pp. 6554-6561.

[35] Vojtí̌sek-Lom M., Cobb J.T. (1997). Vehicle mass emissions measurement using portable 5-gas exhaust analyzer and engine computer data. Presented at the EPA Emission Inventory: Planning for the Future conference, Research Triangle Park, NC, October 28-30, 1997.

[36] Investigation of Diesel Emission Control Technologies on Off-Road Construction Equipment at the World Trade Center and PATH Re-Development Site. Report prepared by M.J. Bradley \& Associated for the the Port Authority of New York and New Jersey, Materials Engineering Division, contract No. 426-03-001, 2004.

[37] Stotsky A., Kolmanovsky I. (2002). Application of input estimation techniques to charge estimation and control in automotive engines. In: Control Engineering Practice, 2002/10.12, pp. 1371-1383.

[38] http://enginelab.net/support_tree.php?fID=Speed_Density

[39] http://support.moates.net/theory-speed-density/

[40] http://www.maftpro.com/speeddensity.shtml

[41] Heywood J.B. (1988). Internal Combustion Engine Fundamentals. McGraw-Hill, New York, 1988.

[42] De Nicolao G., Scattolini R., Siviero C. (1996). Modelling the volumetric efficiency of IC engines: parametric, nonparametric and neural techniques. In: Control Engineering Practice, 1996, 4.10, pp. 1405-1415.

[43] Servati H. and DeLosh R. (1986). A Regression Model for Volumetric Efficiency. SAE Technical Paper 860328, 1986, doi: $10.4271 / 860328$.
[44] Hendricks E., Sorenson S.C. (1990). Mean value modelling of spark ignition engines. SAE Technical paper 900616, 1990.

[45] Andersson P., and Eriksson L. (2001). Air-to-cylinder observer on a turbocharged SI-engine with wastegate. SAE Technical Paper 2001-01-0262.

[46] Smith L., Fickenscher T., and Osborne R. (1999). Engine Breathing - Steady Speed Volumetric Efficiency and Its Validity Under Transient Engine Operation. SAE Technical Paper 1999-01-0212, 1999, doi: 10.4271/1999-01-0212.

[47] Vojtisek M. (2013). Measurement of real-world exhaust emissions from internal combustion engines using portable on-board exhaust emissions monitoring systems. Habilitation thesis. Faculty of Mechanical Engineering, Czech Technical University in Prague, 2013.

[48] Brettschneider J. (1997). Extension of the Equation for Calculation of the Air-Fuel Equivalence Ratio. SAE Technical Paper 972989, Society of Automotive Engineers, 1997. 